\title{
Integrated methods of combating sheep ectoparasites
}

\author{
$S$. Mavlanov ${ }^{1, *}, U$. Soatov $^{1}, S H$. Kholmatov ${ }^{1}, A$. Amirov ${ }^{1}$, and $U$. Irgashev ${ }^{2}$ \\ ${ }^{1}$ Tashkent State Agrarian University, University str., 2, Tashkent province, Uzbekistan, 100140 \\ ${ }^{2}$ Scientific Research Institute of Veterinary, Al-Beruni str., 35, Taylak hamlet, Samarkand province, \\ Uzbekistan
}

\begin{abstract}
Recently, in various countries of the world, in particular, the USA, Germany, Canada, India and Russia, tangible results have been achieved in the use of biological methods for combating zoophilic insects and ecoparasites, the use of microbiological and pyrethroid preparations with a plant base. Zoophilic insects and mites as ecto- and endoparasites parasitize on the body of animals and people cause infestation, that is, parasitosis (entomoses and acarosis), as a result of which the milk productivity of cattle decreases to $30-40$ percent, meat productivity annually decreases by 10-12 kilograms, and also negatively affect the growth and development of young animals and lead to death.
\end{abstract}

\section{Introduction}

In Uzbekistan, large-scale measures are being taken to reduce the level of infection of livestock by zoophilic insects and ectoparasites, to treat, prevent and control pests [1]. An active fight is underway against these insects, infecting livestock with various infectious and invasive diseases, causing a lag in their development, a decrease in productivity, and as a result of an acute disease - the forced slaughter and death of cattle and small ruminants. In livestock enterprises, modern methods and preparations with a pyrethroid base are used to combat the distributors of various diseases by zoophilic insects [2].

In various regions of the world, in the fight against zoophilic insects, chemical agents are used that negatively affect the resistance of the livestock organism and the environment, at the same time, such agents have caused adaptation and, accordingly, the reproduction of pests that cause diseases [3]. In this regard, there is a need for the development of a biological and integration system for combating zooparasites, the creation and implementation of biological, ecological and other optimal methods and means that are harmless to the environment, the body of people and animals, fauna and useful flora $[3,4]$. In this direction, the widespread use of useful entomophages, the creation of new types of highly effective microbiological and pyrethroid drugs and their production in modern and improved formulations are relevant [5].

As a result of world research, a number of scientific results have been obtained on the use of useful entomophages against zoophilic insects, the method of their industrial

\footnotetext{
* Corresponding author: s.mavlanov71@mail.ru
} 
reproduction, the use of microbiological and phytopyrethroid drugs that are harmless to the ecology and nature against ectoparasites [6,7]. Currently, scientific research is being carried out in the world on the use of useful entomophages in the fight against zoophilic insects and their industrial reproduction in the following priority areas: the use of useful entomophages in poultry and pig farms; ways of getting bacterial drugs into the body of arthropods, combating ixodid ticks using microbiological drugs; improving pyrethroid drugs to combat ectoparasites $[1,8,9]$.

However, in animal husbandry, studies on the reproduction of useful entomophages in the fight against zoophilic insects, the use of microbiological and pyrethroid drugs in the fight against ectoparasites of animals have been carried out at an insufficient level.

\section{Materials and methods}

The number of exterminators of zoophilic insects, their larvae and pupae was determined by ecological and entomological methods. Families, genera and species of entomophages and zoophilic insects were determined according to insect guides [2, 3, 5, 6]. Morphological and microscopic methods were used to determine morphology, genitals, and eggs, stages of development and structure of other organs of the S. cameroni fighter. The results of the study (biometric data) were calculated by the method of variation statistics [8]. Sex and number of zoophilic insects were determined using microscopes MBS-1 and MBI-1 while the mass of dead ectoparasites (percentage, number) was calculated according to Abbot's formula $[2,5]$. When determining the insecticidal effectiveness of $25 \%$ cypermethrin, materials of the World Health Organization and methodological manuals were used [7].

\section{Results and discussion}

Data analyzes show that the use of entomophages in animal husbandry practice to control zoophilic insects requires the introduction of biomaterial production on an industrial basis. For the use of entomopathogenic bacteria of the Bacillus thuringiensis group in the fight against harmful insects in ticks, it is necessary to establish the production of bioinsecticide. To use the local drug cypermethrin against widespread ectoparasites, it is necessary to increase production at the Navoi Electrochemical Plant and develop an arsenal of insecticides.

More than 1.5 million species of harmful insects live on our planet. In nature, every animal has pests, which are also home to more than 10 thousand parasites. For example, carnivorous and parasitic arthropod noxious insects have natural pests, which play an important role in the biological balance.

The biological method is a method of using beneficial parasites and predators, microorganisms, and phyto-based pyrethroids to regulate harmful populations or maintain their number to an economically harmless level while creating cheap and environmentally friendly methods and means.

Therefore, it is recommended to use phyto-based insecticides (pyrethroids) and microbiological, which do not have a toxic effect on beneficial entomophages and fighters.

At the same time, protection of biological diversity and ensuring the biobalance of species are of great regulatory importance.

Parasites are living creatures, ecto and endoparasites of larger animals. They feed on harvested cells and fluids. According to the characteristics of infection of their own cells and development, parasites are divided into two groups (Table 1):

1. Parasites that infect insect larvae and complete their development in their pupae;

2. Parasites that infect the pupa of an insect and complete their development in it. 
Table 1. Zoophilous fly parasites.

\begin{tabular}{|c|c|c|c|}
\hline \# & Larvae parasites & $\%$ & Owner \\
\hline $\begin{array}{l}1 \\
2\end{array}$ & $\begin{array}{c}\text { Hymenoptera } \\
\text { Braconidae } \\
\text { Aphaereta minuta Nees } \\
\text { Aphaereta difticilis Nixon }\end{array}$ & 10.3 & $\begin{array}{c}\text { R.striata F., B.melanura } M g . \\
\text { B.haemorrhoidalis Flln. } \\
\text { B.melanura Mg. }\end{array}$ \\
\hline $\begin{array}{l}3 \\
4\end{array}$ & $\begin{array}{l}\text { Ichneumonidae } \\
\text { Atroctodes sp. } n . \\
\text { Stilpnus sp.n. }\end{array}$ & & $\begin{array}{c}\text { R.striata F., B.melanura } M g, . \\
\text { B.haemorrhoidalis Flln. } \\
\text { R.striata F. }\end{array}$ \\
\hline 5 & $\begin{array}{l}\text { Eucoilidae } \\
\text { Eucoila trichopsila hartig }\end{array}$ & 24.2 & $\begin{array}{l}\text { R.striata F., B.melanura Mg., } \\
\text { B.haemorrhoidalis Flln. }\end{array}$ \\
\hline $\begin{array}{l}6 \\
7\end{array}$ & $\begin{array}{l}\text { Chalcididae } \\
\text { Brachymeria minuta L. } \\
\text { Brachymeria sp.n. }\end{array}$ & 65.5 & $\begin{array}{l}\text { R.striata F., B.melanura Mg., } \\
\text { B.haemorrhoidalis Flln. } \\
\text { B.haemorrhoidalis Flln. }\end{array}$ \\
\hline & & 100 & \\
\hline \multicolumn{4}{|c|}{ Pupae parasites } \\
\hline 8 & $\begin{array}{c}\text { Pteromalidae } \\
\text { Spalangiidae } \\
\text { Spalangia cameroni Perkins }\end{array}$ & 14.8 & $\begin{array}{l}\text { M.d.vicina Macq. } \\
\text { M.stabulans Flln. } \\
\text { S.calcitrans L. }\end{array}$ \\
\hline 9 & Spalangia subpunctata Foerster & 8.6 & S.stercoraria l. \\
\hline 10 & Spalangia nigroaenea Curtis & 47.8 & $\begin{array}{l}\text { M.d.vicina Macq., M.stabulans Flln., } \\
\text { S.calcitrans L., M.autumnalis Deg., } \\
\text { F.canicularis L., P.cadaverina F., } \\
\text { Ocaesarion Mo } R \text { striata F }\end{array}$ \\
\hline 11 & Spalangia endius Walker & 1.1 & $\begin{array}{c}\text { M.d.vicina Macq., S.calcitrans L., } \\
\text { F.canicularis L. }\end{array}$ \\
\hline 12 & Spalangia rugulosa Fo"rster & 0.4 & $\begin{array}{l}\text { M.stabulans Flln., O.capensis W., } \\
\text { S.calcitrans L. }\end{array}$ \\
\hline 13 & Spalangia nigripes Curtis & 0.3 & $\begin{array}{c}\text { L.irritans I., M.d.vicina Macq., S.calcitrans } \\
\text { L. }\end{array}$ \\
\hline 14 & Spalangia nigra Latr. & 0.3 & M.d.vicina Macq., S.calcitrans L. \\
\hline 15 & $\begin{array}{c}\text { Pteromalidae } \\
\text { Muscidifurax raptor Girault et } \\
\text { Saunders } \\
\end{array}$ & 24.7 & M.d.vicina Macq., P.cadaverina F. \\
\hline 16 & $\begin{array}{l}\text { Diapriidae } \\
\text { Trichopria sp.n. }\end{array}$ & & S.calcitrans $L$. \\
\hline 17 & $\begin{array}{c}\text { Torymidae } \\
\text { Monodontomerus sp.n. }\end{array}$ & & M.stabulans Flln. \\
\hline 18 & $\begin{array}{c}\text { Coleoptera } \\
\text { Cемья - Staphylinidae } \\
\text { Aleochara bipustulata L. }\end{array}$ & 1.8 & $\begin{array}{c}\text { M.d.vicina Macq., R.striata F., } \\
\text { M.autumnalis Deg. }\end{array}$ \\
\hline 19 & Aleochara spp.n. & 0.2 & $\begin{array}{l}\text { R.striata F., B.melanura Mg., } \\
\text { B.haemorrhoidalis Flln., M.d.vicina Macq., } \\
\text { M.autumnalis Deg., F.canicularis L., } \\
\text { O.caesarion Mg., M.stabulans Flln., } \\
\text { Morellia simplex Lw. }\end{array}$ \\
\hline & & 100 & \\
\hline
\end{tabular}


During the study, it was found that Brachymeria minuta dominated among the larvae of parasites, in the total volume of collected larvae of parasites they amounted to 65.5 percent, Eucoila trichopsila - 24.2, Aphaereta minuta - 10.3 percent, the total volume of detected entomophages was 6.5 percent.

Puppet parasites are widespread in zoobiocenoses (secondary biocenoses), among them Spalangia nigroaenea dominate and account for 47.8 percent of all parasites, besides that Muscidifurax raptor with 24.7 percent, Spalangia cameroni with 14.8 percent, and Spalangia subpunctata with 8.6 percent were also found. The rest of the species accounted for 4.1 percent overall. In the course of the study, it was found that in the total volume of collected entomophages, whereas puppet parasites accounted for 93.5 percent.

This table was supplemented with the creative use of the information and methods of $\mathrm{N}$ Azizov [10], GA Viktorov [11], A Ruzimurodov and N Azizov [12], and M Kholboyev [13]. During the study, 19 species of parasites were found on livestock farms, of which 7 species infect the larvae of zoophilic flies, 12 species - infect their pupae (Table 1).

Among them, the largest number is the Spalangia species. On livestock farms, 47.8 percent of fly pupae are infected with $S$. nigroaenea, 24.7 percent - M.raptor, 14.8 percent S. cameroni, and 12.7 percent of pupae with other species (Table 2).

Table 2. Infection of puparia flies with parasites in a livestock farmю

\begin{tabular}{|c|c|c|}
\hline$\#$ & Entomophages & Percentage \\
\hline 1 & Spalangia nigroaenea & 47.8 \\
\hline 2 & Muscidifurax raptor & 24.7 \\
\hline 3 & Spalangia cameroni & 14.8 \\
\hline 4 & Spalangia subpunctata & 9.8 \\
\hline 5 & Aleochara bipustulata & 2.5 \\
\hline 6 & Aleochara spp.n. & 0.4 \\
\hline & Total & 100 \\
\hline
\end{tabular}

The parasites found in livestock farms can be divided into 3 groups according to the level of content in biotopes:

1. Dominant species - S. nigroaenea;

2. Subdominant species - M.raptor, S.cameroni;

3.Rare species - B.minuta, S.endius, S.rugulosa, S.nigripes, S.subpunctata, A.minuta, E.trichopsila, A.bipustulata, S.nigra, A.spp., A.difticilis , Brachymeria sp., Atroctodes sp., Stilpnus sp., Trichopria sp., Monodontomerus sp.

In the course of this work, scientific studies of the distribution of dominant and subdominant species S. nigroaenea, M.raptor and S.cameroni in livestock farms were carried out, which in the future can be considered as promising, their presence, distribution, biological characteristics, morphological characteristics, and their practical effectiveness in the fight against harmful insects.

Spalangia cameroni Perkins (family Pteromalidae, subfamily Spalangiinae, Spalangia Latreille) accounts for 14.8 percent of the total number of parasites common in livestock farms. Their activity in cattle farms increases from late April to early December. These pests are more common during the summer and fall months. According to the samples collected in the spring months, it was found that they are more common in the month of May (up to 6.2 percent). At the end of May, June and July, the reproduction of the species is observed, according to verified samples, it was found that their volume increases and in August reaches 10.5 percent. 
Spalangia nigroaenea Curtis (family Pteromalidae, subfamily Spalangiinae, genus Spalangia Latreille, 1805) paralyze almost 10 species of zoophilous mosquitoes. Parasites are activated from February and occur until November. A high level of pest infestation of M.d.vicina pupae in dry manure is observed from late May to late June (17.7 percent), then this indicator decreases and increases again by the autumn months. The pest is more common in manure with an importance level of 60-70 percent, with an average temperature of $26-28^{0} \mathrm{C}$ (60-62 percent), and less in manure with a low moisture level of 20-30 percent and a high temperature of $34-36^{\circ} \mathrm{C}(5-7$ percent). In cattle manure mixed with wet straw, fly pupae are heavily infested with pests in the third decade of July and in the second decade of August - up to 41 and 43 percent. Often found in the months of September and October.

Muscidifurax raptor Girault et Saunders (family Pteromalidae, subfamily Pteromalinae, genus Muscidifurax Girault at Saunders, 1910) are parasitic pupae of zoophilous mosquitoes, according to the level of distribution in livestock farms, following the species, more strongly infect their prey in manure with low humidity (20-30 percent) and high temperature $\left(35-37^{\circ} \mathrm{C}\right)$.

From the above data, it follows that $S$. nigroaenea, M. raptor, and $S$. cameroni more infect pupae of synanthropic and zoophilous mosquitoes and have a bioequal, biopermanent, biocenotic significance. In this regard, in the fight against zoophilic insects noted in zoobiocenoses, their parasites $S$. nigroaenea, M. raptor, and $S$. cameroni can be used as a means of biological control to protect biodiversity, ecology, and epidemiological stability.

These useful entomophages are also widespread on poultry farms; there is evidence that they can be widely used to reduce the number of zoophilous mosquitoes in the territory. They, reproducing in pupae of pests not only in animal droppings, but also in human excrement in an open environment, play an important (biosanitary) role in creating a biocenotic favorable environment.

Experiments on the reproduction of domestic mosquitoes in laboratory conditions were carried out in an insectarium. For this, glass jars with a capacity of $0.2-0.1$ liters and special test tubes were used. The necks of the vessels were covered with coarse calico fabric. In the process of their development in thermostats and laboratories, a temperature of $24-26^{\circ} \mathrm{C}$ and a humidity of $65-70$ percent were provided.

For the reproduction of entomophages, 10-15-50 parasites were placed separately in glass jars and test tubes, and in various ratios they were given 10, 20, 50, 100, 500 young pupae. The pupae remained in the vessels for two days, and then they were replaced by one-day-old pupae in the same volume. The pests were fed with sugar syrup, honey solution, water.

If in the process of breeding entomophages are fed with honey solution, the number of females increases and they can be used for a long time. If it was necessary to accelerate the reproduction of pests, it was revealed that the development process is accelerated when the infected pupae are stored at a temperature of 30 degrees. If infected pupae are placed in a refrigerator with a temperature of 3-4 degrees and a humidity of 80 percent, their development slows down (20-30 days).

Based on the studies carried out, it has been established that the expected entomocidal result is achieved during the colonization of entomophages - parasites for each head of a cow fed on a farm, on average, 250 pieces, for one bird - on average, 2 pieces.

As a result of the study, it was established that entomophages are well adapted to develop only in pupae of flies, which does not have a negative impact on nature, ecology and biodiversity. It has been established that during the reproduction of entomophages, providing them with 24-48-hour pupae in a ratio of 1:5 gives a high result of infection of the host's puparia. 
For the reproduction of zoophilic mosquitoes in laboratory conditions, the preparation of the following diet is allowed: a mixture of wheat feed $(0.9 \mathrm{~kg}), 1500 \mathrm{ml}$ of water, $250 \mathrm{ml}$ of milk or skim milk (skim milk). This is considered the optimal feed. For further use of mature pupae, at 24-48 hours of age, they can be stored for a long time in the refrigerator at a temperature of $0^{\circ} \mathrm{C}$.

Experimental studies of the practical application of pests (in livestock farms) were carried out on the territory of a dairy farm of the joint-stock company Taylak administrative district of Samarkand province. For this, in August and September, 2000 entomophages Spalangia grown in the laboratory were placed in the farm's manure storage each time. Before the placement of entomophages, 100 pupae of the zoophilous fly were collected from the biotope (from various parts of the manure storage) and the level of their natural infestation with parasites was established. After placing the parasites in the manure storage, pupae were collected once a week, the level of their infestation by pests was determined and the data obtained were analyzed.

An experiment conducted in August showed that the natural infestation of zoophilic flies by pests was 10.5 percent, after the use of entomophages, the infestation level was 21.7 percent. Observations carried out in September gave the following result: natural infestation of zoophilic flies with pests was 11.2 percent, after the use of entomophages, the level of infestation of pupae of zoophilic flies increased to 35.5 percent.

Tests of entomophages were carried out in September - October at a dairy farmer of the Uzbekistan farm in Saykhunabad administrative district in Syrdarya province. For the experiment, 2000 Spalangia parasites were colonized in the farm's manure storage. After that, once a week, pupae were collected in the manure storage and the development of pests was determined.

In the course of inspections before the experiment, it was found that on the territory of the farm, the natural infection of pupae of zoophilous flies with parasites is 6.5-8.4 percent, after the application of entomophages in the manure storage; this figure was 17-33 percent (Table 3).

Table 3. Infection of the population of M.d.vicina with entomophages Spalangia (MTF 'Taylak' Joint Stock Company).

\begin{tabular}{|c|c|c|c|c|c|}
\hline \multirow{2}{*}{$\begin{array}{c}\text { Mon } \\
\text { ths }\end{array}$} & \multirow{2}{*}{$\begin{array}{l}\text { \# of } \\
\text { exp. }\end{array}$} & \multirow{2}{*}{$\begin{array}{c}\text { Number of } \\
\text { colonized } \\
\text { entomophages }\end{array}$} & \multicolumn{3}{|c|}{ Colonization results } \\
\hline & & & $\begin{array}{c}\text { Hatched } \\
\text { parasites, \% }\end{array}$ & $\begin{array}{l}\text { Hatched } \\
\text { flies, \% }\end{array}$ & $\begin{array}{c}\text { Undeveloped or } \\
\text { destroyed puparia,\% }\end{array}$ \\
\hline \multirow{2}{*}{ July } & 1 & 2000 & 16.2 & 59.7 & 24.1 \\
\hline & 2 & 2000 & 13.4 & 57.3 & 28.7 \\
\hline \multirow{2}{*}{ Aug } & 3 & 2000 & 22.1 & 51.5 & 26.4 \\
\hline & 4 & 2000 & 21.3 & 53.7 & 25.2 \\
\hline \multirow{2}{*}{ Sep } & 5 & 2000 & 35.5 & 42.7 & 21.8 \\
\hline & 6 & 2000 & 31.3 & 45.1 & 23.6 \\
\hline
\end{tabular}

As a result of scientific research, the species of entomophages that can be effectively used to combat widespread zoophilic insects in livestock farms have been identified, and a technology for the cultivation of entomophages has been developed. Based on the above facts, it can be concluded that when using this type of pest in the fight against zoophilic flies on livestock farms, their number is reduced by 2-4 times (16.8-35.5 percent). 


\section{Conclusions}

In zoobiocenoses of Uzbekistan (secondary biocenosis or livestock farms), 27 species of zoophilic insects are common, spreading pathogenic ectoparasites, infections and invasions. Of these, M..d.visina are considered dominant, S.calcitrans - subdominant species. P.alternata, S.pallidiventris, C.supplicans, S.fuscipes are considered new species of zoophilous mosquitoes in the fauna of Uzbekistan.

As a result of the study, it was found that 19 species of parasite-entomophages of zoophilic insects are found in coprobionts (4 of them were identified in the course of the study as new entomophages). Of these, $S$. nigroaenea are dominant, $S$. cameroni and $M$. raptor are subdominants. In nature, they are involved in the biological regulation of more than 10 species of zoophilic flies.

Natural populations of S.cameroni in zoobiocenoses to 16.0 percent, with specially conducted experiments, reduces the number of zoophilous flies to 35.5 percent. This parasite can be effectively used as a biological agent (entomophage) to regulate the number of zoophilic flies in livestock farms (regardless of their form of ownership) and complexes.

\section{References}

1. S. Mavlanov, International Journal of Applied Research, 2(11), 159-161 (2016)

2. C. Geden, H. Biale, E. Chiel, D. Johnson, Journal of Medical Entomology, 56(6), 1650-1660 (2019)

3. S. Broski, B. King, Journal of Economic Entomology, 110(1), 282-287 (2017)

4. S. Mavlanov, Veterinary Medicine, 7, 14-15 (2019)

5. E. Burgess, A. Kremer, S. Elsawa, B. King, BioControl, 62(1), 53-60 (2017)

6. S. I. Mavlanov, Journal of Veterinary, 1, 33-35 (2011)

7. V. Maiquez, J. Pitzer, C. Geden, Journal of Economic Entomology, 187(3), 181-188 (2019)

8. K. Betelman, A. Caspi-Fluger, M. Shamir, E. Chiel, FEMS Microbiology Ecology, 93(9), fix107 (2017)

9. L. De Pedro, J. Tormos, A. Guzmán, B. Peris, F. Beitia, International Journal of Pest Management, 66(4), 311-318 (2020)

10. N. Azizov, Journal of Zoology, 51(6), 925-926 (2017)

11. G. Viktorov, Ecology of Parasite, 4(17), 44-49 (2016) (in Russian)

12. A. Ruzimuradov, N. Azizov, Entomophagous Zoophilous Flies, 1, 1-46 (2017)

13. M. Kholboev, Parasites of zoophilic flies of livestock breeding complexes in Uzbekistan, PhD thesis, 324 (1990) 